\title{
1. The territories of 'sustainable' innovation: from local milieus to 'responsible' communication - the cases of photovoltaics and sustainable finance in Western Switzerland
}

\section{Christian Livi, Pedro Araujo and Olivier Crevoisier}

\subsection{INTRODUCTION}

How do local dynamics play a role in sustainable development? The present chapter addresses this question on the basis of two case studies of sustainable innovation: in the photovoltaic industry in Western Switzerland and in sustainable finance in Geneva.

The innovative milieu approach aims precisely at understanding how local players maintain their competitiveness in global environments. However, it was developed at a time when resources were considered to be mostly immobile and when the issue of sustainability was not as urgent as it is today. How should this approach be adapted to reflect current economic and territorial dynamics?

The approach through innovative milieus, and more broadly by territorial innovation models (TIMs) (Moulaert and Sekia, 2003), shows how local context generates specific types and forms of innovations, and conversely it allows understanding of the spatial form which is produced by those innovations. In this case, what territories develop from 'sustainable' innovations? Specifically, what do these innovations consist of, what networks of actors will produce them, what is sustainability for the consumers of these products and services and, finally, what are the territorial shapes that characterize these changes? To sum up: are territorial approaches capable of shedding light on what is called 'sustainable development'? 
The questions addressed in this book focus on a certain number of points. Firstly, the issue of sustainability requires going beyond standard industrial innovation. Technology, for example, remains a key point, and is often expected to meet certain environmental standards. However, sustainable innovations have a considerable cultural and symbolic dimension. Communication and governance are also part of the innovation, in such a way that it is no longer possible to dissociate those aspects from the result of the innovation, as was mostly the case in traditional industrial innovation. Consequently, the market and customers can no longer be thought of as a simple outlet. Taking communication and governance issues into consideration makes producer-customer relations more complex. Innovation cannot be seen as the embodiment of knowledge in 'things', but also as the embedding of goods in culture. The society's expectations are not only expressed by consumption, but also and perhaps primarily through communication processes between producers, consumers and other stakeholders. Of course, consumers and stakeholders do not generate the same territorial interdependence as technical or production networks.

Secondly, the organization of production and of companies is very different today from what it was in the 1990s. Innovative small and mediumsized enterprises (SMEs) are no longer the centre of the model. The major groups listed on the stock market largely control production and markets. The dominant pattern seems to be that of global production networks (Coe et al., 2004): networks that connect remote regions in order to better use their complementarities. These networks have resulted in exacerbating competition and inducing new spatial hierarchies. Territorial forms of organization, articulating both local dynamics and strong remote interactions, have developed. The question is now of how local dynamics have been reinforced or possibly weakened by these remote relationships. Has 'local' been deconstructed or, on the contrary, does it remain a driving force to enable the participation of local stakeholders in current economic dynamics? These questions affect the various aspects of economic activity, from initial ideas to final consumers, through technological development, production and market construction.

\subsection{CONCEPTUAL FRAMEWORK AND METHODOLOGY}

To analyse two cases covered by this research, we use the following concepts. First, we have identified how the innovations studied were expected to contribute to sustainability. This was not a simple task as sustainability remains a very general concept which, when observed in situ, easily leads to 
criticism. In other words, sustainable innovations always go hand in hand with social debates, or at least are accompanied by discourses explaining and justifying the sustainable dimension of such products, services or activities. In this chapter, and in line with the 'actually existing sustainability' approach, these dimensions have been considered as intrinsic components of the economic as well as social value of these innovations.

Following this, we have listed the various actors actively involved in the innovation networks that produce these changes and have identified competition and cooperation rules governing such networks. Note that these actively involved stakeholders are much more numerous than in the conventional innovative milieus (research centres, innovative SMEs, and so on). When dealing with sustainable innovation, they include more or less specialized media, non-governmental organizations (NGOs), institutional players, communities of practices, opinion leaders and so on.

To understand the complex relations between all those players, we have mobilized the concept of 'convention' (Callon et al., 2002; Eymard-Duvernay et al., 2006; Salais and Storper, 1993), understood as a set of reciprocal expectations for channelling the uncertainties related to the transaction. These expectations include common forms of evaluation of the economic and cultural value of the products, services or activities in question.

Finally, we have characterized the territoriality of those networks, that is, the role of proximity and distance, of the here and the elsewhere, of the local, the national and the global, of the past, the present and the future. By comparing these results with the ideal-type of the innovative milieu, we can characterize the conceptual adjustments required to take into account changes related to sustainable development.

In this chapter, case studies are not used to provide a comprehensive understanding of the photovoltaic and of the financial milieus in Western Switzerland. The aim is to answer the research questions set by the ASLInn project (Kebir et al., Introduction of this book).

Both studies were conducted between May and September 2011. They consisted of documentary work, primarily the collection and analysis of newspaper articles, and two series of semi-structured interviews. These were conducted with company management, research institutes, foundations and public services involved in the development of the innovations. Observations and various contacts were also made at events (fairs, forums). In total, 17 interviews were conducted on photovoltaic (PV) activities in Western Switzerland, and 15 on sustainable finance in Geneva. 


\subsection{THE PV INDUSTRY IN WESTERN SWITZERLAND}

\subsubsection{The Creation of the Photovoltaic Environment: The Central Role of Diversification of Application}

Innovations in the PV industry have developed in two directions: radical innovations which relate to core technologies forming technological trajectories (Nelson and Winter, 1982; Wenting, 2008), and diversified final products or services elaborated on the basis of these technologies.

In Western Switzerland, research on photovoltaic technologies emerged in the 1980s with the opening in 1984 of the photovoltaic laboratory (PVLab) at the Institute of Microtechnology of Neuchâtel (IMT), currently affiliated with the Swiss Technology Institute of Lausanne. This has enabled the creation of many start-ups and attracted research and development $(\mathrm{R} \& \mathrm{D})$ units of large companies in the region. In Lausanne, the Swiss Technology Institute has devoted much attention to research on photovoltaics, largely through the contributions of Professor Grätzel creator of the Grätzel photovoltaic cell which is currently under laboratory investigation. Here too, different start-ups and companies were created.

In turn, the companies in the sector focused on the production of cells and products using such cells. Until the 1990s, companies in the region concentrated their production around crystalline silicon cells. The latter still account for the bulk of the current world market. During the 1990s, research conducted in Western Switzerland and elsewhere enabled the creation of thinfilm cells, much thinner but with less energy efficiency than the previous cells.

Thus, the thin-film modules were the tool used in Western Switzerland to create cells able to produce flexible solar panels, easily transportable and foldable. Despite the proliferation of photovoltaic products on the market, the PV industry does not match the model of radical innovation or functional obsolescence (Packard, 1960); instead, the entire range of photovoltaic cells types develops in parallel through new research that increases efficiency and yield.

Generally, each technology developed follows a dual development. On the one hand, we seek to improve the efficiency of photovoltaic cells. On the other, photovoltaic technologies give rise to new types of more sophisticated cells, whose performance is not necessarily higher but nevertheless open the door to new applications.

In this context, the 2000s represent a key period in the photovoltaic industry in Western Switzerland. We have witnessed increasing diversification of applications. Despite ongoing research provided by the laboratories for photovoltaic yields, diversification of applications has mainly been caused in two 
ways. Firstly, the presence of local technologies has enabled entrepreneurs to have tools capable of creating new devices or innovative products. Secondly, diversification stems from a response to the development of the global photovoltaic market, involving just as many Asian countries as Western ones. Diversification of applications enables local actors to differentiate from the strong Asian competition with innovative products and services.

Despite the use of various technologies, many projects and products have common features in communication, technical and industrial aspects. Some of them are devoted mainly to raising public awareness of sustainable themes, while others are more involved with conventional industrial production logic. Here are some examples:

- PlanetSolar is a solar boat project which achieved a world tour fuelled exclusively by solar energy. This project - designed in Western Switzerland but made in Germany - aimed at raising awareness of public opinion by demonstrating the efficiency of photovoltaics.

- Despite less media attention, the solar tricycle Magic Turtle comes within the same logic. It is an alternative means of transport mainly supported by public authorities and cities, which use it to raise awareness.

- In a more industrial perspective, Grove Boats produces solar boats intended primarily for public sector customers for tourism and ecological uses. These boats are often used to transport tourists during visits to cities such as Venice.

- Flexible photovoltaic cells developed locally have helped to make many solar energy-related products. This is the case of Iland Green Technologies, a local start-up that - using flexible cells developed by Flexcell - produced a tube for transporting a battery and a flexible solar panel, giving access to a source of energy wherever you are.

\subsubsection{The PV Industry in Western Switzerland: Multiple Local Relationships Raising Consumer Awareness}

The photovoltaic environment in Western Switzerland is characterized by two distinct systems (Figure 1.1): the design system and consumer space. The design system refers to the sphere in which innovations and photovoltaic skills are developed: public laboratories engage in research, improvement and development of photovoltaic technologies; large companies - located in the region but also abroad - are especially dedicated to the creation of production chains that require the skills of research laboratories for increased efficiency of photovoltaic cells; start-ups mainly focus on the diversification of applications using the 


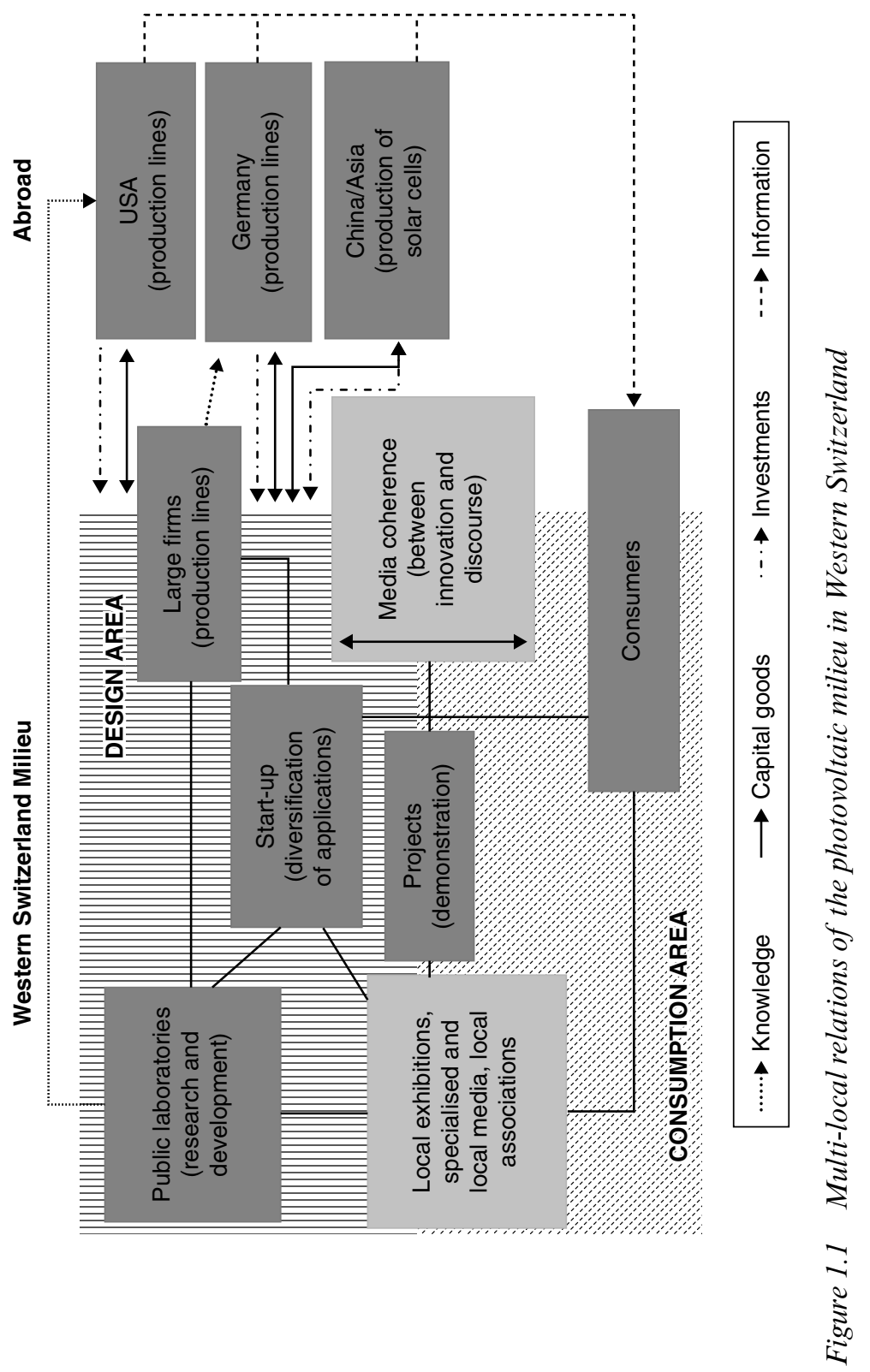


technologies developed in the region, and applying them to concrete products in order to industrialize them. Among these actors, skills are continuously circulating and combining, because if the laboratories provide the skills to corporations, these corporations provide the start-ups and local businesses with the latest generation of photovoltaic cells. Flexcell is a fine example because it resulted from expertise from the public research laboratory, and it provided components to local start-ups. This company, however, had to close its doors due to Asian competition.

The consumption space represents not only the environment in which the consumer buys the product, but also the sphere of gathering information, drawing up communication and spreading the word about it. Consumers and potential users become aware of the existence of photovoltaic products in relation to their aspirations for sustainable development. Subsequently, they can identify with the discourse and ideology that accompany the product itself. Therefore, the value assigned to the product does not result solely from its technical aspects per se, but also the sales pitch that embodies and transmits the product. Similarly, businesses and entrepreneurs that carry these projects are perceived and valued as carriers of a sustainability message.

These innovations combine these two aspects, production and consumption. Solar projects can be considered as hybrid. On the one hand, they are valued as tools applying new photovoltaic technologies. Plus they represent means of demonstrating the progress of solar technologies with regard to public opinion. The most flagrant example in our study is PlanetSolar. This project seeks to raise public awareness about the effectiveness of photovoltaics, but without any productive purpose per se.

However, for system design and consumer space to coexist, we need a discursive consistency between actors in the sector. Entrepreneurs argue their narratives through their productions, while consumers adhere to these narratives by disseminating their commitment, by purchasing products and demonstrating their interest in the debates surrounding their development. In this context, the media and the public authorities are involved as third party and legitimizing intermediaries. They consistently offer the majority of positive feedback to innovations. There is therefore a real social desirability, and those products offer a partial response.

Other relations also address technical, financial and territorial issues. Government laboratories work hand-in-hand with foreign institutes and companies by providing the skills necessary for creating increasingly efficient production lines. Often, these large companies have set up a research and development laboratory in the region to acquire expertise and fundamental knowledge. This will then be forwarded to their parent company in Germany or Japan to create efficient production lines and increasingly 
profitable photovoltaic cells. Roth \& Rau is a fine example of this type of strategy: the German company has located its laboratory near the public photovoltaic laboratory in order to capture new technologies that can be used in its factories. There are also foreign influences on this sector through different methods. Firstly, foreign companies provide capital in the form of equipment used by local businesses. Secondly, foreign investors bring their capital into play in the industrialization phase of local actors' photovoltaic products. From a financial standpoint, start-ups traditionally innovate through local capital granted by local investors or public authorities. The case of Iland Green Technologies is a good example, since capital comes from the entrepreneur's social network. However, from the industrialization phase, start-ups and new businesses are often bought by companies listed on the stock exchange, or related to private investors who provide the capital necessary for expansion. They are often willing to invest large sums of money in projects or in the production of new applications. This was the case of Flexcell - now closed - which was bought in the early phase of its industrialization by Q.Cells, a German multinational producer of photovoltaic cells.

Countries such as the United States (US) or Germany, or regions such as East Asia, have a major impact on the economy of the photovoltaic sector of Western Switzerland. From a technical point of view, the Western countries are more orientated towards the creation of production lines. The countries of South East Asia - mainly China - are orientated towards the production of low-cost solar cells. These cells, even if they belong to the older generation of photovoltaic cells, offer consumers advantageous value compared to European and American output.

However, the creation of a global photovoltaic market raises different questions about the production and consumption of products presented as 'sustainable'. On the one hand, numerous small and large Western companies are currently struggling to cope with competition from Chinese and Indian products that are equally efficient but less expensive on the market. Due to this, various firms have been forced to restructure or close. Research and development of new photovoltaic technologies has failed to overcome the widening gap in the relationship between panel product performance and prices on the market.

On the other hand, widening organization between the local innovation system and remote places is developing in the symbolic and media field. During our research, we found that analysis of the construction market in the photovoltaic industry should include both productive aspects and consumer expectations and behaviour. To identify the construction of the photovoltaic market in comprehensive terms, the ratio between production and consumption and the debates developed between them, we used the 
'convention' tool (Callon et al., 2002; Eymard-Duvernay et al., 2006; Salais and Storper, 1993).

\subsubsection{Photovoltaics: Technical Justification with a Sustainable Convention to Commit}

In a conventionalist approach, producers and consumers are bound by a convention that reduces uncertainties by means of a common form of evaluation. In this case, we will speak of a 'sustainability convention' (Gabriel and Gabriel, 2004-2005, 203) characterized by technological issues, market and 'civic' dimensions, projection into the future, and a link between the local and global scales. It postulates the energy and environmental dangers inherent in the current system, and their assimilation by the consumer. This sustainability convention is also based on the notion of responsibility, which translates as an 'openness to environmental and social concerns in the development and deployment of innovations shared between different societal actors' (Ingham, 2011, 32). Every action performed is subject to social control and judged by public opinion as being responsible, not responsible or even irresponsible.

In the cases observed, the entrepreneur is often portrayed in a symbolic manner. The entrepreneur provides a response - albeit very partial - to aspirations to a clean and efficient future energy in a commodity form. They become an interpreter for saving the planet while remaining in a production-consumption system sustained by innovation. Differentiating from the simple producer, the entrepreneur connects as an innovative spirit in a spirit of stage management engaged in sustainability, promising to find solutions to global environmental problems and working for the wellbeing of a community. The seller therefore portrays themself as a 'responsible' contractor, coming within a sort of 'defensive and remedial design' continuing to reduce the environmental damage caused by industrial civilization (Djellal and Gallouj, 2009, 61). This commitment supports the distinction between public opinion of what is responsible and what is not.

Quality conventions 'not only define how the quality of an object is assessed within a community of production and consumption but also how it is controlled and legitimized' (Jeannerat, 2009, 29). The production of sustainable goods implies that the products must be imbibed with certain values approved by the society (Djellal and Gallouj, 2009). In this context, the customer does not just purchase a product to use, but also an argument concerning innovations and their utility, and a more or less elaborate type of social control enabling verification of compliance.

From this perspective, the customer of the PV industry is not a simple user assessing the technical features of the solar product. The customer, or 
consumer, nurtures a sustainable discourse and adheres to the social value construction of the product. The customer is a responsible user, because the relationship with the producer does not stop with the purchase, but they co-produce a meaning (Ritzer and Jurgenson, 2010) and diffuse the message (Tremblay, 2011).

In this configuration, the strategy put in place by the entrepreneur and their company aims to show product features to users and the general public and to provide them with a publicized argument on solar technologies and sustainable development. Then, it is just a question of staging a public performance capable of confirming the potential of the product, but also to incite consumers to increased use of renewable energy. Thus, the justification for the use of photovoltaic products has evolved; today, raising consumer awareness concerns the commitment to sustainability rather than the technical characteristics of the goods.

For solar products (for example, solar panels made of silicon), quality is assessed by its use and the exchange established between the responsible user and entrepreneur. Technology certifies the narratives handed out by entrepreneurs. Quality is subject to social control, which identifies any possible irresponsibility on the part of the actors and possible technical defects in the products. This control becomes 'a true control body conferring legitimacy' (Gabriel and Gabriel, 2004-2005, 206) that evaluates the product and its underlying message. However, for solar projects, evaluation is publicized during industrial testing (for example a world tour in a solar boat). The testing will serve as proof of the performance of these new technologies. The solar boat innovation rests on a demonstration with global feedback on the features of solar energy.

As we have noted, the legitimizing third parties (particularly NGOs, the media and public authorities) are becoming essential to spreading the message about sustainable development and for the demonstration of new developments and entrepreneur commitment (Jeannerat, 2009; Tremblay, 2011). Actors in marketing and communication can therefore be considered as effective in disseminating images, channelling social control and increasing credibility within public opinion on a national and global level.

The ideal type of production-consumption community shows the potential socio-economic risks and rewards coordinating this relationship (Figure 1.2). Despite current political and social debates concerning the abandonment of nuclear power, solar innovation remains based on personal and local entrepreneurial motivation. The responsible entrepreneur develops a technological innovation sold to users and validated through the legitimizing sphere. This innovation should not be seen as a simple product; it is the support of social values that draws the user. Distribution and dissemination of solar products among users is made possible by the 


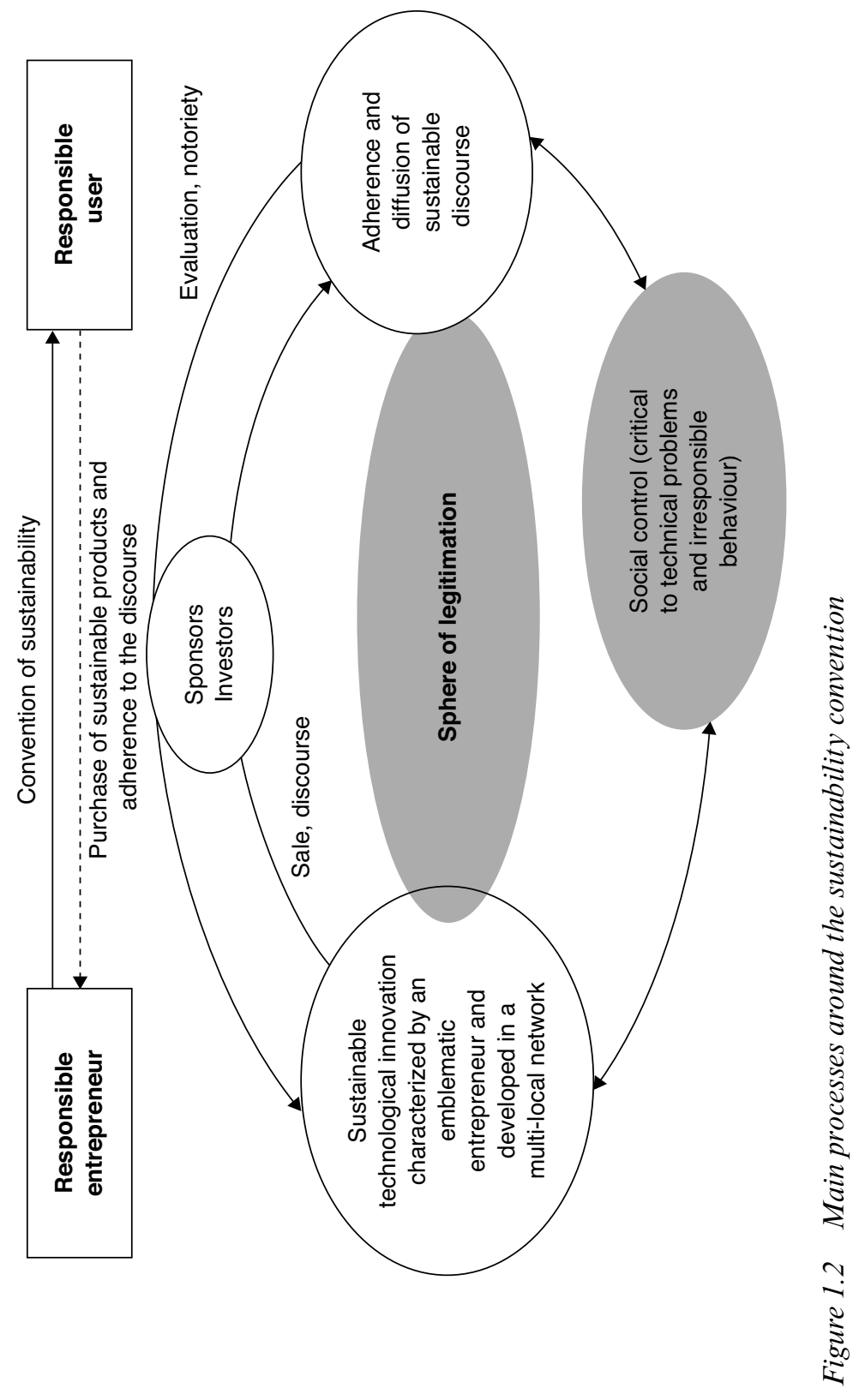


narratives built around sustainable innovations that give public legitimacy to technological development. The responsible consumer evaluates the transmitted message and subscribes by purchasing the product and disseminating the argument on sustainability. For their part, sponsors and investors subscribe to the argument and the future prospects of the entrepreneur by sponsoring innovation and making a profit from it, either monetary or in terms of acknowledgment. Subscription of investors to photovoltaic projects whose financial profitability is low is explained by a return in terms of reputation.

According to Dujarier $(2008,154)$, 'companies need to create an environment in which customers are concerned about the impact of their behaviour on other consumers'. In this context, the criticism that legitimizes these products may also turn against the practices and products of emblematic entrepreneurs. This social control also allows the stigmatization of technical problems and irresponsible behaviour.

\subsection{SUSTAINABLE FINANCE IN GENEVA}

Since its emergence in the late 1890s, the Swiss financial centre has grown from a small local economic sector composed of a few hundred employees to one of the major international financial clusters in the world (Mazbouri, 2005). It occupies, as such, the position of global leader in cross-border wealth management for non-residents (ASB, 2011). This extraordinary growth is partly due to a policy implemented in the early twentieth century by Swiss banking circles, which was to make Switzerland a country of refuge for individuals seeking to protect their capital from the national treasury (Guex, 2002). This competitive advantage, enhanced by the Banking Act of 1934 prohibiting the violation of banking secrecy, now seems to be on the decline amid international pressure which is demanding more transparency and more cooperation with the tax authorities. Faced with these new requirements, the actors in the Swiss financial place are being forced to redefine a new strategy to maintain their position among the largest international financial centres.

The Swiss Bankers Association (SBA) and the Federal Council have developed a plan to promote their banking sector, now based on managing declared assets. This new positioning goes hand in hand with the production of new discursive strategies, whose aim is to present an internationally accepted financial centre, and the mobilization of new resources and skills to maintain the attractiveness of the Swiss financial centre. It is in this turbulent context that some financial players have seized upon the potential risks and rewards related to sustainable development to rebuild the 
legitimacy of their industry. This is particularly the case of the sustainable finance sector of the financial centre of Geneva.

\subsubsection{Identification of Innovation}

Sustainable finance - also known as 'ethical finance', 'green funds' or 'socially responsible investment' (SRI) - is a concept that refers to all the strategies used by finance professionals to include the potential risks and rewards related to sustainable development in the products and services they offer to private and institutional investors. This integration is achieved by creating environmental, social and governance criteria - otherwise known as ESG - that complement traditional financial measures of managing investment funds. Performance of investments underpinning sustainable finance is not determined exclusively by reference to the financial return, as is the case in traditional finance, but also in terms of the assessment of the level of sustainability of the funds. To measure performance in terms of sustainable development of funds, financial professionals use a wide variety of approaches (Table 1.1).

Table 1.1 Key sustainable finance strategies identified in Geneva

\begin{tabular}{cl}
\hline Strategy & Sustainability component \\
\hline $\begin{array}{c}\text { Normative } \\
\text { exclusion }\end{array}$ & $\begin{array}{l}\text { Applying a negative filter, excluding a business portfolio that does } \\
\text { not meet certain expectations based on sustainable performance } \\
\text { standards, values or minimum thresholds (negative screening) }\end{array}$ \\
\hline $\begin{array}{c}\text { Normative } \\
\text { inclusion }\end{array}$ & $\begin{array}{l}\text { Applying positive screening, including in a portfolio corporate } \\
\text { securities that may be more efficient in their sector in terms of } \\
\text { sustainable development (best-in-class, positive screening) or } \\
\text { whose main activity is linked directly with environmental or } \\
\text { societal issues (thematic funds) }\end{array}$ \\
\hline Commitment & $\begin{array}{l}\text { Dialogue with the companies present in a portfolio of securities } \\
\text { in order to promote socially responsible practices }\end{array}$ \\
\hline Shareholder & $\begin{array}{l}\text { Exercise of shareholder voting rights through the services of a } \\
\text { financial professional }\end{array}$ \\
\hline Integration & $\begin{array}{l}\text { Application of ESG criteria by the financial professional in the } \\
\text { analysis of asset classes }\end{array}$ \\
\hline Microfinance & $\begin{array}{l}\text { Providing financial services to a population often excluded from } \\
\text { the traditional financial system }\end{array}$ \\
\hline Direct & $\begin{array}{l}\text { Long-term investment outside financial markets in companies } \\
\text { that have strong potential in terms of sustainable performance } \\
\text { (impact finance) }\end{array}$ \\
\hline investment
\end{tabular}


These strategies are not mutually exclusive, but may be complementary. Thus, it is not uncommon for financial management companies to practise normative inclusion of certain funds - for example, thematic funds for renewable energies - and also to propose a monitoring policy on the sustainable development of the enterprises concerned (commitment).

Regardless of the chosen strategies, the development of sustainable finance requires the establishment of a control mechanism allowing finance professionals to produce expertise in an area that was previously unknown to them. It is precisely the creation of expertise on sustainable evaluation of companies that is at the core of this innovation. The establishment of such a criterion requires mobilizing new resources and new skills. From a territorial standpoint, this means a new use of local resources including the networking of actors working in sustainable finance, and also the use of internationally constituted standards.

\subsubsection{Relationships Within the Sector}

The sustainable finance sector in Geneva is characterized by the interweaving of a logic of competition and a logic of cooperation. Within this set-up, we can distinguish the various kinds of relationships between financial professionals, according to the spaces in which they are located. We distinguish three distinct areas in the relationships observed in the sustainable finance sector in Geneva: an area of supply, an area of exchange and an area of demand (Figure 1.3).

The supply area consists of all financial professionals who create sustainable financial products and services. Among them, we find the big banks, the cantonal bank, private banks, asset management companies and startups. All of these companies operate in a competitive environment where trading relations between them are not frequent, although possible.

Control of virtually all stages of production of sustainable innovation is largely made possible by the development of local expertise. Companies benefit from the strong concentration of skills rooted in Geneva in terms of private wealth management. These skills have been available internally for banks and wealth management companies for a number of years. The case for start-ups is significantly different. In all the start-ups we studied, the director had always worked for several years in other Geneva-financial companies, sometimes even already specialized in sustainable finance, before setting out on their own. According to the work of Wenting (2008) on the fashion industry, this situation shows the importance for financial actors of becoming financially literate in large banks or renowned private banks before developing sustainable financial products and services in their own companies. 


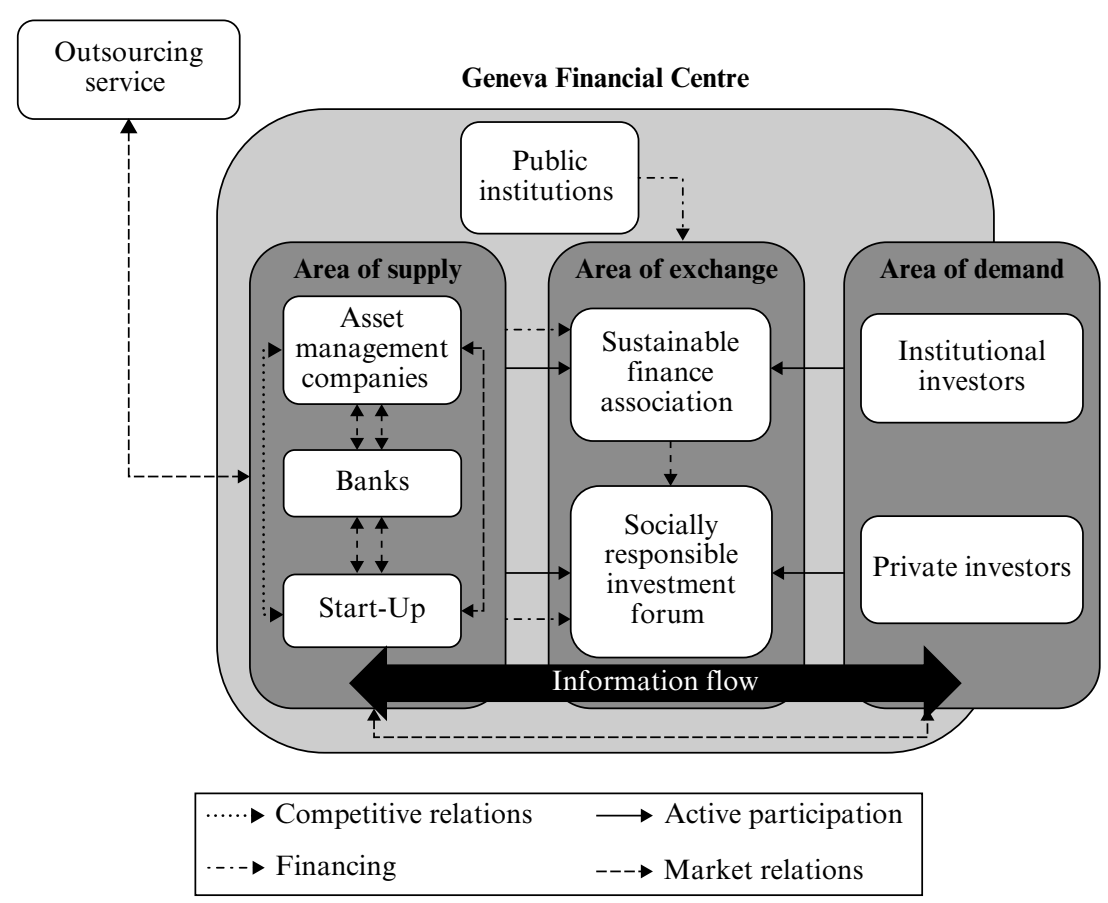

Figure 1.3 Relations in the sustainable finance sector

If the financial analysis skills are mobilized locally, this is not always the case for extra-financial analysis skills. Access to extra-financial information is a key issue since the quality of sustainability depends on this information. In some cases, this information is also obtained through the work of internal extra-financial analysts. More often it is purchased from rating agencies or is extra-financial research based in other regions.

According to Julien and Marchesnay (2011), the exchange of information and services between the various producers depends on the social capital built up by the actors in the innovation network. This social capital is established within the area of exchange. It includes a strong network around one association, Sustainable Finance Geneva, which includes among its members most of the professionals in sustainable finance in Geneva. Funded both by the state of Geneva and by subscriptions from its members, this association, founded in 2008, arranges regular workshops where each member is invited, if they so desire, to present new ideas for the development of sustainable finance in Geneva. Membership is completely free. Each individual expressing an interest in the issues addressed by the 
association has the opportunity to become a member. Members subscribe individually and formally undertake not to represent the interests of their companies, should they work in the financial sector. This commitment obviously does not exclude the products and services of actors in sustainable finance being presented and discussed during the meetings of the association.

More than just a forum of ideas on sustainable finance, these meetings in an associative framework also make it possible to structure professional relations between the various actors. For example, during our field survey we observed that some actors, notwithstanding being in competition, do not hesitate to exchange business information or to ask each other for advice.

Sustainable Finance Geneva is also responsible for the creation of an annual forum on sustainable finance. This serves as a venue privileged space for linking up with potential customers for sustainable products and services. Also through this forum, the Geneva financial centre can gain improved local, national and international visibility. It should be emphasized that the main target of the actors in the supply area is still the pension funds - especially local pension funds. The establishment of a platform such as this forum is a clear sign of wanting to inform potential customers.

Finally, the demand area corresponds with the target clientele for sustainable finance. Financial professionals mainly target two types of customers: private customers with a significant fortune (high net worth individuals, HNWIs) and pension funds. According to Eurosif (2011) estimates, HNWIs are a category of customer that should show major growth in coming years. Given that Geneva is a financial centre known for its private wealth management, it is not surprising that many private banks offer sustainable products: Pictet, Lombard Odier, de Pury Pictet Turrettini \& Cie and Mirabaud. This customer base, established over many years, is usually loyal to its wealth manager. The trawling of increasingly mobile foreign capital is one of the essential issues of all financial sectors.

\subsubsection{A Sustainability Convention in Finance}

The underlying discourse to practices related to sustainable finance postulates the unsustainability of the current economic and financial system. In environmental terms, this system will result in both an energy deadlock and irreparable repercussions on the climate; while socially it will not contribute to general well-being over the long term. Like the Fair Trade discourse that empowers and politicizes the consumer, intrinsic discourse on sustainable finance places the investor in a position to change the destiny of the world. By offering investment taking into account the challenges of 
sustainable development, sustainable finance provides a response to these criticisms in commodity form. The financial institution and the investor, often seen as sensitive only to the performance of their investments, are now presented as actors enabling financial capitalism to persist through financial innovation, and as responsible social agents facing the future of the planet.

In doing so, financial actors postulate the possibility of building 'social and environmental performance' (Penalva Icher, 2009). This management requires the creation of a monitoring system allowing financial institutions and investors to measure the quality of what is perceived as socially responsible. Banks and companies active in this type of management are developing new internal competencies: extra-financial analysis. This can be performed by a financial analyst or by persons unskilled in financial engineering. In both cases, the analysis requires mobilization of new skills and new knowledge.

There are two categories of socially responsible investors: private investors and institutional investors. For both, this type of investment usually responds to a need for consistency between the search for profitability and the will to not produce actions that could be harmful to society and the environment. Investors search for equal or increased profitability in making investments proposed by the sustainable finance sector; this is a fundamental criterion set by banks and asset management companies. Thus, it is important to show customers that this type of investment is just as, if not more, cost-effective than traditional investments. In the case of sustainable finance, a system including a set of indicators is developed by the financial institutions, to ensure that their customers are informed of the evolution of the social and environmental situation of the companies. This can be done in some cases, as for the Sarasin bank, with the direct involvement of the investor.

Taking the investor's sensitivity into account is an important component of the system set up by banks and management companies to legitimize their position of 'socially responsible'. This building of legitimacy is founded on transparent information about social and environmental aspects. Some banks such as Pury Pictet even offer to enter into a regular dialogue with the companies in which they invest, in order to report to investors the objective situation and progress in sustainability. The assessment of a company's sustainability usually precedes the financial analysis.

Banks and management companies develop their products within their internal structures with very few intermediate players. These are limited to extra-financial analysis companies that sell raw information from databases on companies. Thus the money creation process is the result of internal activity in the financial market, where all the company's activities 
are contained in the same location, or of an activity developed between financial marketplaces and marketed by each of them (Figure 1.4). In the first case, we can cite as an example the Pictet bank, which develops its sustainable funds exclusively in Geneva. Conversely, a bank such as Sarasin will only carry out sales, and part of its management, in Geneva. However, any extra-financial analysis will be performed at the company's registered office in Basel. If the creation process does not involve a lot of different areas, management is spread over multiple premises. Thus, sustainable funds sold in Geneva will be managed by asset managers based in other financial centres such as Paris or London. The skills mobilized are therefore strongly anchored in various closely connected financial sectors at medium and long distance, more or less complementary, more or less in competition (Crevoisier et al., 2011). Maintaining the sustainability convention stems directly from the circular relationship between the three types of key players in the convention: investors, managers and companies (Figure 1.4).

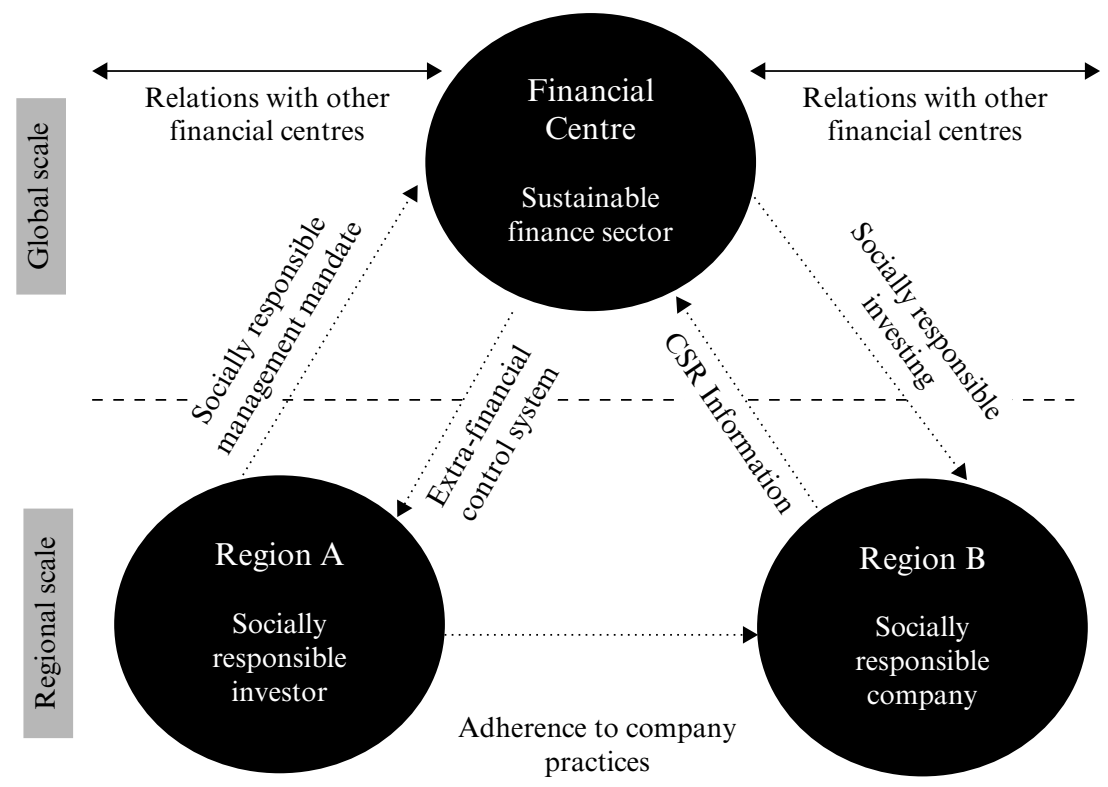

Note: $\quad$ CSR $=$ corporate social responsibility

Figure 1.4 Territories and sustainable finance agreement 


\subsection{COMPARISON OF THE TWO CASES}

What we have called the sustainability convention (Table 1.2) appears as a central sustainable innovations system, a system that redefines the relationship between the producer and consumer in photovoltaics, or between financial intermediaries and investors. Within both the photovoltaic industry and sustainable finance, the sustainability convention is based on the notion of responsibility. For producers, consumers and investors, their actions must be responsible in their own eyes and in those of public opinion. Despite sectorial differences, the argument is conveyed by third parties or intermediaries in order to legitimize the value of the product supplied. In this configuration, standard sales pitch and market presentation have evolved considerably. The exchange between producer and consumer is more based on communication, social interaction and social control. Similarly, the valuation of goods and services stems less from the physical and functional characteristics of products and services, but more from appropriateness with the projection towards the future that is the aspiration to sustainable development.

Beyond this common and defining point, a certain number of specific points differ between the photovoltaic industry and sustainable finance. Firstly, the contexts in which the photovoltaic industry in Western Switzerland and the sustainable finance industry in Geneva are developing are very different. The PV industry represents the emergence of a new sector, characterized mainly by the creation of new businesses in the region and the will of many entrepreneurs to find solutions to environmental issues. However, sustainable finance in Geneva is a growing sub-sector within a well-established industry; sometimes in agreement with it, other times not.

Secondly, public communication is carried out differently in the two cases. The PV industry aims at widespread legitimacy, obtained from the general public and public authorities. Concrete actions in terms of energy and environmental protection are used as the basis for a responsible corporate image. Sustainable finance, on the other hand, seeks membership in a specific environment in order to attract investors interested in sustainable funds. These innovations not only provide a companion product for traditional financial vehicles, but also represent a potential model of transition to a possible sustainable financial capitalism. Communication in the sustainable financial world differs according to the investors. Institutional investors seek to show their responsible commitment to their policyholders. As for private investors, it is probably to improve their own self-image, or to stay any public criticism, that they subscribe to such products. 


\section{Table 1.2 Summary of the sustainability convention for the financial and photovoltaic industries}

\begin{tabular}{|c|c|c|}
\hline $\begin{array}{l}\text { Quality conventions } \\
\text { within the production- } \\
\text { consumption community }\end{array}$ & $\begin{array}{l}\text { Photovoltaic industry } \\
\text { sustainability convention }\end{array}$ & $\begin{array}{l}\text { Financial sustainability } \\
\text { convention }\end{array}$ \\
\hline Basis of the convention & \multicolumn{2}{|c|}{ Responsible or not responsible } \\
\hline Type of tenderer & \multicolumn{2}{|c|}{ Responsible contractor / Financial management } \\
\hline Type of applicant & \multicolumn{2}{|c|}{ Responsible user / Investor } \\
\hline Quality legitimacy & $\begin{array}{l}\text { Technical test live and } \\
\text { effective link-up between } \\
\text { discourse and technical } \\
\text { set-up submitted to } \\
\text { criticism }\end{array}$ & $\begin{array}{l}\text { Effective link-up between } \\
\text { discourse and technical set } \\
\text { up demonstrating extra- } \\
\text { financial performance }\end{array}$ \\
\hline Merchant exchange & $\begin{array}{c}\text { Sponsorship, product and } \\
\text { argument }\end{array}$ & $\begin{array}{l}\text { Traditional commission } \\
\text { and yield }\end{array}$ \\
\hline $\begin{array}{l}\text { Time of quality } \\
\text { evaluation by the } \\
\text { final applicant }\end{array}$ & $\begin{array}{c}\text { During the industrial test } \\
\text { or through a continuous } \\
\text { social control }\end{array}$ & $\begin{array}{l}\text { Continuous process, at the } \\
\text { time of the investment and } \\
\text { throughout management }\end{array}$ \\
\hline $\begin{array}{l}\text { Central element of } \\
\text { innovation }\end{array}$ & $\begin{array}{c}\text { Experience, research } \\
\text { and demonstration of } \\
\text { technology backing up } \\
\text { argument }\end{array}$ & $\begin{array}{l}\text { Control research on the } \\
\text { extra-financial dimension } \\
\text { of companies }\end{array}$ \\
\hline Market link & \multicolumn{2}{|c|}{$\begin{array}{l}\text { TV ratings, circulation and distribution / } \\
\text { participation }\end{array}$} \\
\hline $\begin{array}{l}\text { Type of territorial } \\
\text { relationship } \\
\end{array}$ & \multicolumn{2}{|c|}{ Multi-site and media } \\
\hline $\begin{array}{l}\text { Potential intermediary } \\
\text { risks and rewards } \\
\text { linked to marketing } \\
\text { and communication }\end{array}$ & $\begin{array}{l}\text { Co-construction of the } \\
\text { publicized undertaking in } \\
\text { favour of sustainability }\end{array}$ & $\begin{array}{l}\text { Construction of the } \\
\text { concepts of sustainability } \\
\text { and responsibility, } \\
\text { intermediate as industrial } \\
\text { type suppliers }\end{array}$ \\
\hline
\end{tabular}

Source: Own elaboration from Jeannerat (2009).

\subsection{CONCLUSION}

ASLInn research (Kebir et al., 2010) explores the idea that 'sustainable innovations' are associated with forms of business anchoring processes different from those described in the 1990s (territorial innovation models, 
especially in innovative sectors). What are the lessons that can be drawn from the two case studies?

Regarding resources, the innovations observed certainly mobilize traditional resources, such as knowledge from research institutes. In addition, they make intense use of natural resources for cultural and symbolic purposes, focusing on media 'buzz' - in the case of photovoltaics - especially by playing intensely with the values of commitment and responsibility that characterize sustainable innovations. It is upon these components that not only the social, but also the economic values of these innovations is based. The ability to manage these symbolic dimensions appears as central in sustainable innovations: positively, when the value can be based on recognition of responsibility; and negatively, when these innovations are criticized. Note also that these cultural resources refer less to the past, to tradition, and more to an aspiration towards a greener and more equitable future for the planet.

The enhancement of these innovations - in the sense of the social process that leads to a positive or negative value, even a price, for these innovations - is complex and takes place in different spheres, through different actors: the goods and services market; public awareness; the power to influence the framing of public policies; or the decisions of some companies. These innovations also mobilize more stakeholders than the traditional sectors: the mainstream media, consumers, citizens (in the case of photovoltaics), NGOs, pension funds, the specialist press, international organizations (in the case of sustainable finance), in addition to training and research companies and institutions. In fact, all the players likely to exercise social control or have the ability to offer legitimacy have become important.

Both sectors observed are also integrated into long-distance value chains. The traditional model - innovate and produce locally to sell on a global market - has been replaced by the insertion of local production activities and consumption closely related to medium- to long-distance interactions. During the past years, the rise of China's photovoltaic industry has led to the establishment of a division of labour on an intercontinental scale. This has shattered the vision of regional or national clusters that would develop on the basis of a local market characterized by stricter environmental and social standards. In sustainable finance, however, it is the local consumers (regional and national pension funds) that nourish these innovations. Financial flows, information and NGO activities unfold in the globalized arena.

Finally, public action, in the case of photovoltaics, covers numerous aspects: encouragement of technological research, aid for the formation of associations involving all interested actors, standards for 
territorial planning, demonstration projects, legitimizing through contests and awards, and so on. In the case of finance, private actors seek to stand out from state actors. However, the fact remains that demand from public pension funds is a major force of innovation in this sector.

\section{ACKNOWLEDGEMENTS}

This research was conducted as part of the GREMI-T network. Research into photovoltaics has been integrated into the European Science Foundation's 'Cluster Life Cycle' project, funded in part by the Swiss National Fund for Scientific Research (application no. 105517_133256). This chapter was written jointly by the three authors. Nevertheless the photovoltaics case study was conducted by Christian Livi, and that of sustainable finance by Pedro Araujo.

\section{REFERENCES}

Association Suisse des Banquiers (ASB) (2011), La gestion de fortune en Suisse, ASB, Bâle.

Callon, M., Meadel, C. and Rabeharisoa, V. (2002), The Economy of Qualities, Economy and Society 31(2), 194-217.

Coe, N.-M., Hess, M., Yeung H., Dicken, P. and Henderson, J. (2004) 'Globalizing' Regional Development: A Global Production Networks Perspective, Transactions of the Institute of British Geographers 29(4), 468-484.

Crevoisier, O., Theurillat, T. and Araujo, P. (2011), Les territoires de l'industrie financière: quelles suites à la crise de 2008-2009?, Revue d'économie industrielle 134(2), 133-158.

Djellal, F. and Gallouj, F. (2009), Innovation dans les services et entrepreneuriat: au-delà des conceptions industrialistes et technologistes du développement durable, Innovations 1(29), 59-86.

Dujarier, M.-A. (2008), Le travail du consommateur. De McDo à eBay: comment nous coproduisions ce que nous achetons, La Découverte, Paris.

Eurosif (2011), European SRI Study 2010, Eurosif, Paris.

Eymard-Duvernay, F., Favereau, O., Orlean, A., Salais, R. and Thevenot, L. (2006), Valeurs, coordination et rationalité: trois thèmes mis en relation par l'économie des conventions, in Eymard-Duvernay, F. (ed.), L'économie des conventions: méthodes et résultats, La Découverte, Paris, 23-44.

Gabriel, P. and Gabriel, P. (2004-2005), Diffusion du développement durable dans le monde des affaires: un schéma conventionnel, Revue française de Gestion 152, 199-213.

Guex, S. (2002), Le secret bancaire suisse: une perspective historique. Revue économique et sociale: bulletin de la Société d'Etudes Economiques et Sociales 60, 9-19. 
Ingham, M. (2011), Vers l'innovation responsable. Pour une vraie responsabilité sociale, De Boeck, Bruxelles.

Jeannerat, H. (2009), Communautés de production-consommation et convention d'authenticité: peut-on encore parler d'utilisateur horloger?, in Zorick, K. and Courvoisier, F. (eds), L'utilisateur horloger dans un monde en mutation, Hauteécole de Gestion ARC, Neuchâtel, 13-42.

Julien, P-A. and Marchesnay, M. (2011), L'Entreprenariat, Economica, Paris.

Kebir, L., Costa, P., Crevoisier, O. and Peyrache Gaudeau, V. (2010), ASLInn Project description, Anchorage, sustainability and localisation of innovation: towards new forms of territorialisation of economic activities?, December, Paris.

Mazbouri M. (2005), L'émergence de la place financière helvétique (1890-1913). Itinéraire d'un grand banquier, Antipodes, Lausanne.

Moulaert, F. and Sekia, F. (2003), Territorial Innovation Models: A Critical Survey, Regional Studies 37(3), 289-302.

Nelson, R.R. and Winter, S.G. (1982), An Evolutionary Theory of Economic Change, Harvard University Press, Cambridge, MA.

Packard, V. (1960), The Waste Makers, David McKay Company, New York.

Penalva Icher, E. (2009), Construire une qualité pour le 'socialement responsable'?, Revue française de Socio-économie 4, 59-81.

Ritzer, G. and Jurgenson, N. (2010), Production, Consumption, Prosumption. Journal of Consumer Culture 10(1), 13-36.

Salais, R. and Storper, M. (1993), Les mondes de production: Enquête sur l'identité économique de la France, EHESS, Paris.

Tremblay, S. (2011), Développement durable et communication: vers un espace ouvert fondé sur la participation citoyenne, l'éthique du dialogue et l'interinfluence, Télescope 17(2), 239-255.

Wenting, R. (2008), Spinoff dynamics and the spatial formation of the fashion design industry, 1858-2005, Journal of Economic Geography 8, 593-614. 